\title{
Development of an Online Learning Management Framework for Vocational Students in Thailand in the New Normal under the COVID-19 Situation
}

\author{
Rawiphon Charunphankasem ${ }^{1}$ \\ ${ }^{1}$ Rajamangala University of Technology Phra Nakhon, Thailand \\ Correspondence: Rawiphon Charunphankasem, Rajamangala University of Technology Phra Nakhon, Bangkok, \\ Thailand.
}

Received: July 20, 2021

Accepted: August 14, 2021

Online Published: August 23, 2021

doi:10.5430/ijhe.v11n1p151

URL: https://doi.org/10.5430/ijhe.v11n1p151

\begin{abstract}
The objective of this article is developing an online learning management model for vocational students in Thailand based on the New Normal lifestyle under the COVID-19 situation. The sample consisted of 400 teachers and students. The results obtained from the research found that the according to the 17 online instructional design experts who assessed the appropriateness of the online learning management framework based on the New Normal lifestyles under the COVID-19 situation for vocational students in Thailand (OLA Framework), the overall assessment results were excellent due to the conceptual framework being consistent with the objectives, processes, and sequential thinking methods. And Comparison of the mean scores of mathematics learning achievement between the experimental group and the control group had mean scores of 75.13 and 75.47 , respectively. The students in both groups demonstrated no significant difference in learning achievement at the .05 level, indicating that regarding the experiment, students in the online learning group and the traditional classroom learning group demonstrated no difference in learning achievement because the teacher's learning management was consistent with the concept of online learning management in the New Normal lifestyle. The results of the assessment of satisfaction with online learning management were at the highest level because teachers organized learning system according to the conceptual framework, As a result, online learning management meets the learning objectives. The assessment of satisfaction with online learning based on the New Normal lifestyle under the COVID-19 situation among vocational students in Thailand was at the highest level overall.
\end{abstract}

Keywords: online learning, vocational students in Thailand, covid-19

\section{Introduction}

The international standard for vocational students is to teach learners to Innovation, media and technology are important factors in the development of a learning society. vocational students in Thailand, is based on learner-centered principles. It is critical to consider the diversity of learner personalities and lifestyles, which are influenced by their community, society, and Thai culture, in order to lay the groundwork for developing 21 st-century skills (Ministry of higher education, Science, Research, and Innovation, 2020) and assisting them in their global work. Therefore, it is necessary to have a clear direction of development in accordance with the different nature of changing global trends, lifelong learning and develop skills in the future.

The spread of the new coronavirus or COVID-19 virus in late 2019 affects people worldwide and has a negative impact on the economy, society, and education system. Educational institutions are unable to offer traditional classroom instruction. However, in the age of borderless communication and diverse technologies, many educational institutions are able to continue teaching by utilizing multiple technologies as assisting tools in the development of an online teaching system (Pandom, 2020), resulting in adaptation to a new way of life (New Normal). The online teaching method is used to ensure continuity of learning. Teachers and students can communicate with one another using elements and formats which are appropriate for the study course's nature and the learners' context, resulting in the use of digital technology for effective online classroom management (Wayo, 2020) and (Atef Mohammad Abuhmaid, 2020). 
In Thailand's context, organizing online learning in presents a significant challenge, not only in terms of addressing immediate COVID-19-related issues but also in terms of transforming crisis into an opportunity to create a new world of learning and ensuring sustainable learning quality (Pinyosinwat, 2020)

Additionally, this crisis provides teachers with an opportunity to adjust their teaching style, as well as their selection of various tools and technologies that aid in teaching both theoretical and practical sections. Students can more efficiently access knowledge sources, increase their opportunities to learn independently, and review lessons at any time.

The objectives of this research are as follows:

To develop an online learning management model for vocational students in Thailand based on the New Normal lifestyle under the COVID-19 situation, the researcher studies the suitability of the development and makes the following hypotheses:

An online learning management model which is appropriate for Thai vocational students has been developed based on the New Normal lifestyle under the COVID-19 situation.

\section{Research Methodology}

This is a research and development project aimed at developing an online learning management model for vocational students in Thailand based on the New Normal lifestyles under the COVID-19 situation. The sample group is as follows:

1) A sample of 400 teachers and students will be surveyed regarding their opinions on online teaching management. The sample group will be divided into 100 teachers and 300 students (Purposive sampling) in Step 1.

2) 17 online instructional design specialists (Purposive sampling) to evaluate the instructional model developed in Step 2.

3) Certificate of Vocational Education, the second semester of the 2020 academic year, using students from, Nakhornsawan Industrial and community education college, Inburi Industrial and community education college, Khanu woralaksaburi and, Noenkham Industrial and community education college a total of 400 students in semester 2/2020, two classrooms, each with 200 students, totaling 400 students (Purposive sampling) to be used as a sample group in Step 3.

4) In Step 4, five online instructional design experts will assess their satisfaction with the New Normal lifestyle-based online learning management system for vocational students in Thailand under the COVID-19 situation.

5) Certificate of Vocational Education, the second semester of the 2016 academic year, using 200 students (Purposive sampling) from Nakhornsawan Industrial and community education college, Inburi Industrial and community education college, Khanu woralaksaburi and, Noenkham Industrial and community education college in semester 2/2020 to assess their satisfaction with online learning management based on the New Normal lifestyles under the COVID-19 situation for vocational students in Thailand in Step 5.

1: Conduct a needs assessment of teachers and students regarding the online teaching and learning model in order to analyze and synthesize the framework for online teaching and learning management in Thailand. This framework will serve as a guide for defining the scope and teaching method in accordance with the needs.

2: Create a prototype of an online teaching and learning management model.

1) Conduct an assessment of theory, research papers, and the data gathered in Step 1, followed by analysis and synthesizing the data to create a prototype.

From an examination of the current state of an online learning management model based on a new way of life for vocational students in Thailand under the COVID-19 situation, utilizing the TPACK Model (Kurt, 2018), which consists of Technological Knowledge, Pedagogical Knowledge, and Content Knowledge (Kurt, 2018), as illustrated in Figure 1. 


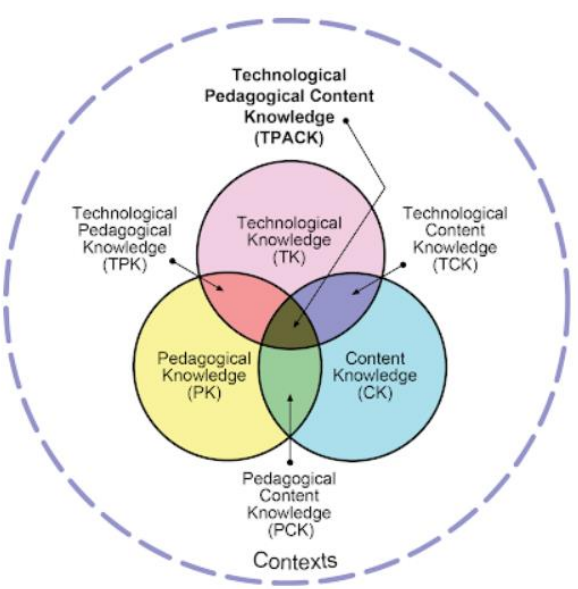

Figure 1. TPACK framework

Figure 1. According to the TPACK framework, it is best to use specific technological tools (hardware, software, applications, and associated information literacy practices) to instruct and guide students toward a more robust understanding of the subject matter. Thus, within the TPACK framework, the three types of knowledge - TK, PK, and CK - are combined and recombined in a variety of ways. Technological pedagogical knowledge (TPK) is concerned with the relationships and interactions between technological tools and specific pedagogical practices; pedagogical content knowledge (PCK) is concerned with the relationships and interactions between pedagogical practices and specific learning objectives, and technological content knowledge (TCK) is concerned with the relationships and intersections between technologies and learning objectives. These triangulated areas then form TPACK, which takes into account the relationships between all three areas and recognizes educators' actions within this complex space. (Kurt, 2018)

The results of a synthesis of research on online learning are summarized in Table 1.

Table 1. The synthesis of online learning

\begin{tabular}{|c|c|c|c|c|c|c|c|c|c|c|}
\hline Characteristic & 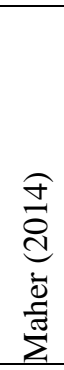 & 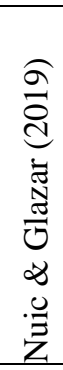 & 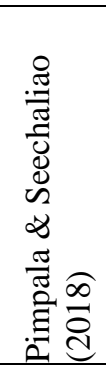 & 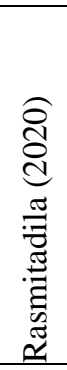 & 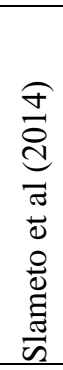 & 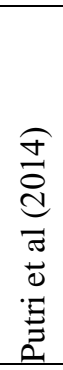 & 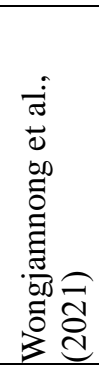 & 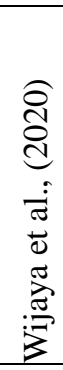 & 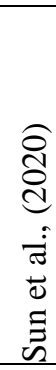 & 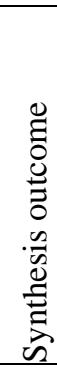 \\
\hline \multicolumn{11}{|l|}{ - Online Learning } \\
\hline 1. Content Knowledge & $\checkmark$ & $\checkmark$ & $\checkmark$ & $\checkmark$ & $\checkmark$ & $\checkmark$ & $\checkmark$ & $\checkmark$ & $\checkmark$ & $\checkmark$ \\
\hline 2. Technology Knowledge & $\checkmark$ & $\checkmark$ & $\checkmark$ & $\checkmark$ & $\checkmark$ & $\checkmark$ & $\checkmark$ & $\checkmark$ & $\checkmark$ & $\checkmark$ \\
\hline 3. Pedagogical Knowledge & & & $\checkmark$ & $\checkmark$ & $\checkmark$ & & $\checkmark$ & & & \\
\hline \multicolumn{11}{|l|}{ - Learning activities } \\
\hline 1. Collaborative learning & $\checkmark$ & & $\checkmark$ & $\checkmark$ & $\checkmark$ & & & & & \\
\hline 2. Constructive learning & & & $\checkmark$ & & $\checkmark$ & & & & & \\
\hline 3. STEM education & & & $\checkmark$ & $\checkmark$ & & & & & & \\
\hline \multicolumn{11}{|c|}{ - Assessing of Learning Outcome } \\
\hline 1. Knowledge & $\checkmark$ & $\checkmark$ & $\checkmark$ & $\checkmark$ & $\checkmark$ & $\checkmark$ & $\checkmark$ & $\checkmark$ & $\checkmark$ & $\checkmark$ \\
\hline 2. Skills & $\checkmark$ & & $\checkmark$ & & $\checkmark$ & $\checkmark$ & $\checkmark$ & $\checkmark$ & & $\checkmark$ \\
\hline 3. Attitude & $\checkmark$ & $\checkmark$ & $\checkmark$ & $\checkmark$ & $\checkmark$ & $\checkmark$ & & $\checkmark$ & & $\checkmark$ \\
\hline
\end{tabular}


The researcher synthesized the conceptual framework for online learning with the goal of improving analytical thinking skills. As illustrated in Figure 2, the researcher studied, researched, analyzed, and synthesized documents, data, and literature pertaining to the online learning process in order to improve analytical thinking skills.

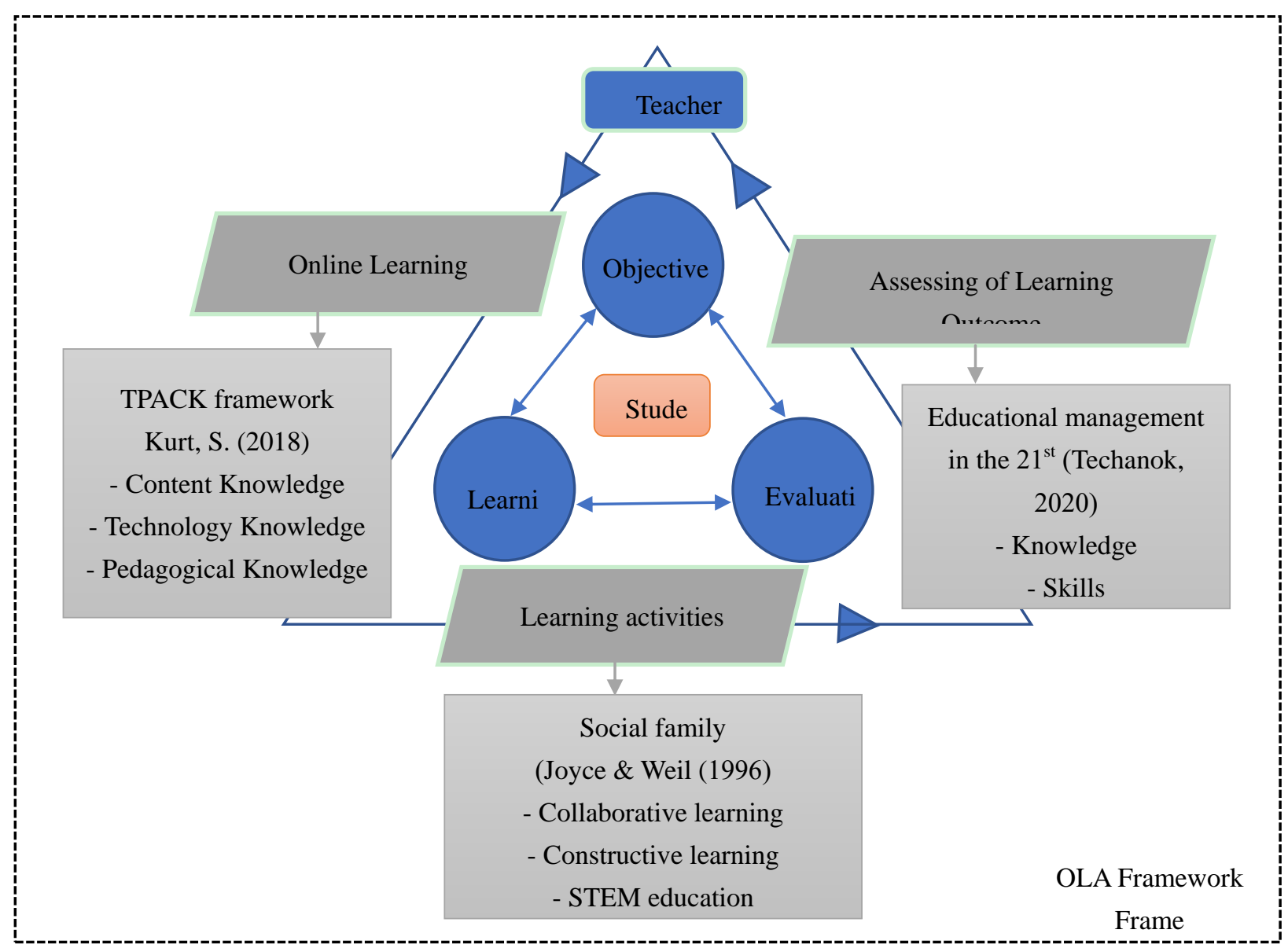

Figure 2. OLA conceptual framework for promoting online learning management based on

the New Normal lifestyles for vocational students in Thailand under the COVID-19 situation

Figure 2. The developed conceptual framework identifies the following steps for online learning management based on the New Normal lifestyles for vocational students in Thailand under the COVID-19 situation as follows:

Step 1: Online Learning: Teachers analyze content related to the subjects in the desired course and select instructional tools and technologies used in teaching to impart knowledge to students, consistent with the research titled the development of online learning packet on e-Learning pedagogy (e-Pedagogy) course for instructors in educational institutes (Stiman \& Thummatha, 2012).

Step 2: Learning activities: Teachers design learning activities that incorporate social processes (Social family), require group dynamics, or require students to interact with others in order to learn, such as Collaborative learning, Constructive learning, and STEM education. The design of appropriate activities for each type is contingent upon a content analysis of the subjects taught by teachers, as demonstrated in the research titled STEM education for vocational students. (Suakong, 2018) and the research titled Development of Creative Thinking for Vocational Certificate Students on the Topic of Daily Life Chemicals by (Krostsalee et al., 2020)

Step 3: Assessing of Learning Outcomes: Teachers employ evaluation methods, and students are evaluated in accordance with 21st-century learning standards based on Competency-Based Assessment: CBA in the following manner:

Knowledge, Skills, and Attitude following the criteria indicate the components of learning and the outcomes that result from the learning process according to the learning standards established for each level of education (Office of the Education Council, 2019). 
2) Present a draft of an online instructional management model developed to 17 experts in online instructional design for them to evaluate the model's appropriateness. The table below summarizes the evaluation criteria for expert opinions (Kanasutra, 1995).

Table 2. Average score range and interpretation

\begin{tabular}{ll}
\hline Average score range & Interpretation \\
\hline $4.50-5.00$ & Highest level \\
$3.50-4.49$ & High level \\
$2.50-3.49$ & Average level \\
$1.50-2.49$ & Low level \\
$1.00-1.49$ & Lowest level
\end{tabular}

3: Comparison of average scores on mathematics learning achievement between experimental group (online learning) and control group (traditional classroom learning). The experimental model used in this research was Randomized Control-Group Pretest-Posttest Design, as shown in the table.

Table 3. Randomized Control-Group Pretest-Posttest Design

\begin{tabular}{llll}
\hline Group & Pretest & Treatment & Posttest \\
\hline $\mathrm{E}$ & $\mathrm{T}_{1}$ & $\mathrm{X}$ & $\mathrm{T}_{2}$ \\
$\mathrm{C}$ & $\mathrm{T}_{1}$ & $\sim \mathrm{X}$ & $\mathrm{T}_{2}$ \\
\hline
\end{tabular}

As shown in Table 3, E denotes the Experimental Group (online learning), C denotes the Control Group (traditional classroom learning), $\mathrm{T} 1$ denotes the pre-experimental test, $\mathrm{T} 2$ denotes the post-experimental test, $\mathrm{X}$ denotes the experiment utilizing a developed online instructional model, and $\sim \mathrm{X}$ denotes traditional classroom instruction.

The sample group for the third step was 400 students in High Vocational Certificate, the second semester of the academic year 2020, who were selected as the experimental group using simple random sampling (online learning) 1 classroom, 200 people, and the control group (traditional classroom learning) 1 classroom, 200 people.

4: The sample group used in Step 4 was five online instructional design experts. The experimental instrument was a satisfaction questionnaire on online learning management for vocational students in Thailand based on the New Normal lifestyle under the COVID-19 situation.

5: The sample group used in Step 5 was 200 students in High Vocational Certificate, the second semester of Academic Year 2020, obtained from a simple random sampling. The experimental instrument was a satisfaction questionnaire for online learning based on the New Normal lifestyle for vocational students in Thailand under the COVID-19 situation.

\section{Conclusion}

Stage 1 - After interviewing teachers about Thailand's online teaching and learning model requirements, it was determined that teachers needed to teach online from a Covid-19 perspective and live in the New Normal.

Teachers need a conceptual framework for managing online learning and must learn how to use technology to assist them in their instruction, such as Google Classroom, e-mail, chat rooms, and web boards. Teachers must be able to utilize hypermedia programs and strategize instruction in accordance with the 21 st-century approach to learning management.

Additionally, when students were questioned about their needs for online teaching, it was discovered that students required online learning as a result of the Covid-19 situation, and as a result of living in the New Normal, students require additional knowledge about online teaching and learning. Students expect teachers to teach in an engaging and simple-to-understand manner, using materials that aid in learning. To study, submit classwork, and send homework, students must have a device that supports online learning via the Internet.

Stage 2 - The results of an assessment of the appropriateness of the online learning management framework for vocational students in Thailand based on the New Normal lifestyle under the COVID-19 situation by 17 online instructional design experts are shown in Table 4. 
Table 4. Results from an assessment of the appropriateness of an online learning management framework for vocational students in Thailand based on the New Normal lifestyles under the COVID-19 situation (OLA Framework)

\begin{tabular}{llll}
\hline Description & Mean & SD & Interpretation
\end{tabular}

1. The learning process developed in compliance with the $4.83 \quad 0.39 \quad$ Highest research objectives

2. Online Learning process components include:

4.75 $\quad 0.45 \quad$ Highest

(1) Input

(2) Process

(3) Output

(4) Feedback

3. Classification of learning process components for designing learning and teaching management is precisely and continuously conducted

4. Learning processes in each component are related to one another

5. Sequencing of learning process components is suitable and easy to understand

6. The overall of learning process components is well $4.83 \quad 0.39 \quad$ Highest organized and covers all essential needs

4.83 $\quad 0.39 \quad$ Highest

Overall suitability

$4.80 \quad 0.41 \quad$ Highest

As shown in Table Table 4, The results of the assessment of the appropriateness of the online learning management framework for vocational students in Thailand (OLA Framework) based on the New Normal lifestyles under the COVID-19 situation are generally at the highest level (mean $=4.80, \mathrm{SD}=0.41$ ). When detailed aspects are considered, it is discovered that each detailed aspect is rated at the highest level, implying that the overall is also at the highest level; thus, the OLA online learning process can be used as a guideline to improve the learning and teaching processes.

Stage 3 - The following table compares the mean scores on mathematics learning achievement between the experimental and control groups:

Table 5. Comparison of mean scores on mathematics learning achievement between experimental and control groups

\begin{tabular}{lllllll}
\hline Learning Achievement & Number of Students & Full score & Mean & SD & T & Sig. \\
\hline Experimental Group & 200 & 100 & 75.13 & 10.69 & 1.26 & 0.104 \\
Control Group & 200 & 100 & 75.47 & 10.35 & & \\
\hline
\end{tabular}

$* * \mathrm{P}>. \overline{05}$

Table 5 Mean post-trial achievement scores for students in the experimental and control groups 75.13 and 75.47 were the mean scores, respectively. Additionally, the statistical significance test revealed no significant difference in learning achievement between the students in the two groups at the .05 level, indicating that after the experiment, the students in the online learning group and the traditional classroom learning group had no difference in learning achievement.

Stage 4 - Assessments of satisfaction with online learning management based on the New Normal lifestyles under the COVID-19 situation for vocational students in Thailand were conducted by five online instructional design experts who observed teachers using the OLA Framework in Mathematics. The results are summarized in the table. 
Table 6. Satisfaction Assessment of the New Normal lifestyles-based Online Learning Management System for Vocational students in Thailand Under the COVID-19 Situation

The New Normal lifestyles-based Online Learning Management System for Mean SD Interpretation Vocational students in Thailand Under the COVID-19 Situation

- Online Learning

1. Teachers are prepared in advance to teach.

4.50 $0.61 \quad$ High

2. Teachers develop knowledge and understanding of educational management's aims and objectives.

3. Teachers have the ability to impart knowledge that aids students in their learning about the subject.

4. Teachers inform students about the tools and technology used in the classroom.

5. Teachers are knowledgeable about online education systems and technology.

6. Teachers are approachable, offer advice, and are receptive to students' perspectives.

- Learning activities

1. Teachers design learning activities that emphasize students' participation in order to foster critical thinking and practice.

2. Teachers incorporate supplementary media and instructional innovations to effectively promote learning for students.

3. Teachers employ a variety of instructional strategies that are appropriate for the subject matter being taught.

4. Teachers have teaching and learning activities that encourage students to conduct continuous research and pursuit of knowledge.

-Assessing of Learning Outcome

1. Teachers assess and evaluate students using a competency-based approach.

2. Teachers evaluate teaching and learning in accordance with the learning activities provided to students and their developmental stage.

3. Teachers provide answers or guides to the answers in order for students to understand the learning outcomes.

4. The teacher revealed the measurements' results.

$4.60 \quad 0.55 \quad$ Highest

4.67

4.60

0.52 Highest

0.55 Highest

$4.60 \quad 0.55 \quad$ Highest

$4.73 \quad 0.48 \quad$ Highest

5. Teachers provide constructive feedback that encourages self-improvement.

4.60

0.63 Highest

$4.73 \quad 0.48 \quad$ Highest

6. Teachers' methods for calculating and evaluating grades are apparent and equitable.

$4.73 \quad 0.48 \quad$ Highest

$4.73 \quad 0.48 \quad$ Highest

$4.60 \quad 0.55 \quad$ Highest

$4.73 \quad 0.48 \quad$ Highest

Overall suitability

4.64 $0.53 \quad$ Highest

Table 6 The results of the satisfaction assessment of online learning management based on the New Normal lifestyles under the COVID-19 situation for vocational students in Thailand were overall at the highest level (Mean $=4.64$, SD $=0.53$ ), indicating that online learning management based on the New Normal lifestyles under the COVID-19 scenario is suitable for vocational students in Thailand.

Stage 5 - assessment of satisfaction with online learning based on the New Normal lifestyle under the COVID-19 situation of vocational students in Thailand Assessed by 200 students (only the students studying online), the results are as follows. 
Table 7. Results of the satisfaction assessment of online learning based on the New Normal lifestyle under the COVID-19 situation of vocational students in Thailand

The New Normal lifestyles-based Online Learning Management System for Mean SD Interpretation Vocational students in Thailand Under the COVID-19 Situation

1. During the COVID-19 situation, students are not required to travel to school.

2. Students have the option of reviewing lessons at any time.

3. Students comprehend the lesson taught by the teacher.

4. Students enjoy learning.

5. Students may communicate with teachers at any time during their lessons.

Overall suitability
4.80

0.41

$\begin{array}{ll}4.83 & 0.78\end{array}$

$4.67 \quad 0.73$

$\begin{array}{ll}4.98 & 0.89\end{array}$

High

Highest

Highest

Highest

$\begin{array}{lll}4.60 & 0.63 & \text { Highest } \\ 4.77 & 0.68 & \text { Highest }\end{array}$

Table 7. The results of the assessment of satisfaction with online learning based on the New Normal lifestyle under the COVID-19 situation of vocational students in Thailand were overall at the highest level $(\mathrm{Mean}=4.77, \mathrm{SD}=$ 0.68), indicate that students are satisfied with online learning based on the New Normal lifestyle under the COVID-19 situation and enjoy learning.

\section{Conclusion and Discussion}

The following sections summarize and discuss the results from a study on an online learning management model based on the New Normal lifestyle under the COVID-19 situation for vocational students in Thailand.

1) Based on teacher and student questionnaire responses, it was determined that teachers and students alike require online learning due to the COVID-19 situation. Both teachers and students must develop the ability to integrate technology and learning in order to create a new way of life.

2) According to the 17 online instructional design experts who assessed the appropriateness of the online learning management framework based on the New Normal lifestyles under the COVID-19 situation for vocational students in Thailand (OLA Framework), the overall assessment results were excellent due to the conceptual framework being consistent with the objectives, processes, and sequential thinking methods.

3) Comparison of the mean scores of mathematics learning achievement between the experimental group and the control group had mean scores of 75.13 and 75.47 , respectively. The students in both groups demonstrated no significant difference in learning achievement at the .05 level, indicating that regarding the experiment, students in the online learning group and the traditional classroom learning group demonstrated no difference in learning achievement because the teacher's learning management was consistent with the concept of online learning management in the New Normal lifestyle (OLA Framework)

4) The results of the assessment of satisfaction with online learning management based on the New Normal lifestyles under the COVID-19 situation for vocational students in Thailand were at the highest level because teachers organized learning system according to the conceptual framework (OLA Framework), for example, teachers must create knowledge and understanding about the objectives and goals of educational management, using a variety of teaching methods suitable for the content of the course. As a result, online learning management meets the learning objectives.

5) The assessment of satisfaction with online learning based on the New Normal lifestyle under the COVID-19 situation among vocational students in Thailand was at the highest level overall because students can review lessons at any time, comprehend the lesson and have fun learning.

\section{References}

Atef, M. A. (2020). The efficiency of online learning environment for Implementing project-based learning: Students' Perceptions. International Journal of Higher Education, 9(5), 76-83. https://doi.org/10.5430/ijhe.v9n5p76

Joyce, B., \& Weil, M. (1996). Models of Teaching. (5 ${ }^{\text {th }}$ ed.). Boston: Allyn and Bacon.

Krostsalee, P., Pansuppawat, T., \& Khamhaengpol, A. (2020). Development of creative thinking for grade 6 students on the topic of daily life chemicals by using Stem education and graphic organizers. Journal of Roi Et Rajabhat 
University, 197(14), 196-209.

Kurt, S. (2018). TPACK: Technological Pedagogical Content Knowledge Framework. in Educational Technology. Retrieved from https://educationaltechnology.net/technological-pedagogical-content-knowledge-tpack-framework/

Maher, D. (2014). Online learning in primary schools. Retrieved from file://C:/Users/ASUS/Downloads/Onlinelearninginprimaryschools.pdf

Ministry of higher education, Science, Research and Innovation. (2020). Policy and strategy for higher education, science, research and development, 2020-2027 and science science, Research and innovation plan, 2022.

Nuic, I., \& Glazar, S. A. (2019). The effect of e-learning strategy at primary school level on understanding structure and states of matter. December 2019. Eurasia Journal of Mathematics Science and Technology Education, 16(2). https://doi.org/10.29333/ejmste/114483

Office of the Education Council. (2019). Guidelines for developing student Competency-Based education. Bangkok: Century Company Limited.

Pandom, S. (2020). How to turn crisis into opportunity of thai vocationity of Thai vocational education on the new normal. Journal of Social Science and Buddhistic Anthropology, 5(7), 1-13.

Pimpala, S., \& Seechaliao, T. (2018). Instructional approach STEM using social media to enhance creative thinking Skills for primary 6 students. Journal of Innovation Technology Management, 5(2), 71-82.

Pinyosinwat, P. (2020). How to organize teaching and learning in the situation of COVID-19: from foreign lessons to Thai learning management. $\quad$ Retrieved $28 \quad$ March $\quad 2021$ from https://tdri.or.th/2020/05/examples-of-teaching-and-learning-in-covid-19- pandemic/

Putri, R. S., Purwanto, A., Pramono, R., Asbari, M., Wijayanti, L. M., \& Hyun, C. C. (2020). Impact of the COVID-19 pandemic on online home learning: An explorative study of primary schools in Indonesia. International Journal of Advanced Science and Technology, 29(5), 4809-4818.

Rasmitadila., Aliyyah, R. R., Rachmadtullah, R., Samsudin, A., Syaodih, E., Nurtanto, M., \& Tambunan, A. R. S. (2020). The perceptions of primary school teachers of online learning during the COVID-19 pandemic period: A Case study in Indonesia. Journal of Ethnic and Cultural Studies 2020, 7(2), 90-109. https://doi.org/10.29333/ejecs/388

Slameto. (2014). primary School e-learning development as a social study learning model in the $5^{\text {th }}$ grade primary school. International Journal of e-Education, e-Business, e-Management and e-Learning, 4(5), 351-360. https://doi.org/10.7763/IJEEEE.2014.V4.350

Stiman A., \& Thummatha, T. (2012). The development of online learning packget on e-Learning pedagogy (e-Pedagogy) course for instructors in educational institutes. Silpakorn Educational Research Journal, 10(1), 91-105.

Sun, L., Tang, Y., \& Zuo, W. (2020). Coronavirus pushes education online. Nature Materials. Nature Materials, 19(6), 687-687. https://doi.org/10.1038/s41563-020-0678-8

Suakong, T. (2018). STEM education for vocational students. Phranakhon Rajabhat Research Journal, 13(2), 223-242.

Techanok, A., Jaronggsirawat, R., \& Vatasatto, P. H. (2020). Educational management in the 21 ${ }^{\text {st }}$, 7(9), 1-15.

Wayo, W. (2020). Online teaching under the epidemic situation of COVID-19: Concept and Application of teaching and learning management. Regional health promotion center 9 journal, 14(34), 285-298.

Wijaya, T. T., Ying, Z., Purnama, A., \& Hermita, N. (2020). Indonesian students' learning attitude towards online learning during the coronavirus pandemic. Psychology, Evaluation, and Technology in Educational Research, 3(1), 17-25. https://doi.org/10.33292/petier.v3i1.56

Wongjamnong, C., Muangou, C., \& Nuangchalerm, P. (2021). Opinions of students and teachers in primary school towards online learning during COVID-19 Outbreak. Pedagogi: Jurnal Ilmu Pendidikan, 21(1), 30-35.

\section{Copyrights}

Copyright for this article is retained by the author(s), with first publication rights granted to the journal.

This is an open-access article distributed under the terms and conditions of the Creative Commons Attribution license (http://creativecommons.org/licenses/by/4.0/). 